\title{
A S D と胸腹部大動脈瘤の同時手術に対する体外循環の経験
}

\author{
国立東静病院 中央手術室 \\ 後藤互井出由美 山本達也 \\ 同 心臓外科 \\ 梅本琢也細井靖夫高木寿人 \\ 吉澤奉伸藤田毅
}

\section{I 、はじめに}

今回我々は, 心房中隔欠損症に合併した胸腹部 大動脈瘤に同時手術を行った症例の体外循環を経 験したのでててに報告する。

\section{II．症例および経過}

症例は66歳, 男性, 既往歴は高血圧, 㹟心症に て近医に通院中であり，59歳で左白内障の手術を 受けている(表 1)。

現病歴は平成元年 9 月背部痛をきたし当科入院。 C T 亿て解離性大動脈瘤 (DaBakey III b 型) と診 断された。2 力月の降圧療法後退院し, 外来にて Follow中洞不全症候群のためペースメーカー植え込 を行った。平成 3 年 10 月初旬, 胸部圧迫感を訴え, 超音波検查抽よび心臓カテーテル検査にて心房中 隔欠損症之診断され再入院となる。

大動脈造影ではエントリーははっきりせず, 腹
腔動脈直上のリエントリーより解離腔が造影され た。腹㻟，上腸管膜動脈および腎動脈はいずれも 真腔から造影された（図 1)。

腹腔動脈直上で，前方へ突出する衰状の瘤を認 めた（図 2 )。

C T では下行大動脈上部では瘤は径 $8 \mathrm{~cm}$ と拡大 しており，一部では偏控の開存が認められた（図 3 )。

胸部X線写真では C T R 61\% と拡大。左前胸部 よりペースメーカー電極が右心室内に挿入されて いる(図 4 )。

心房中隔欠損症と大動脈瘤に対して同時手術を 行うこととし, 平成 3 年 12 月 2 日施行した。

III. 体外循環回路およびモニタリング

手術中の圧モ二ターは, 右樘骨動脈圧, 右足背 動脈圧, 肺動脈圧, 中心静脈圧とし, 体温は直腸 温，膀脱温，深部体温をモニターした。使用肺は

表 1 症 例

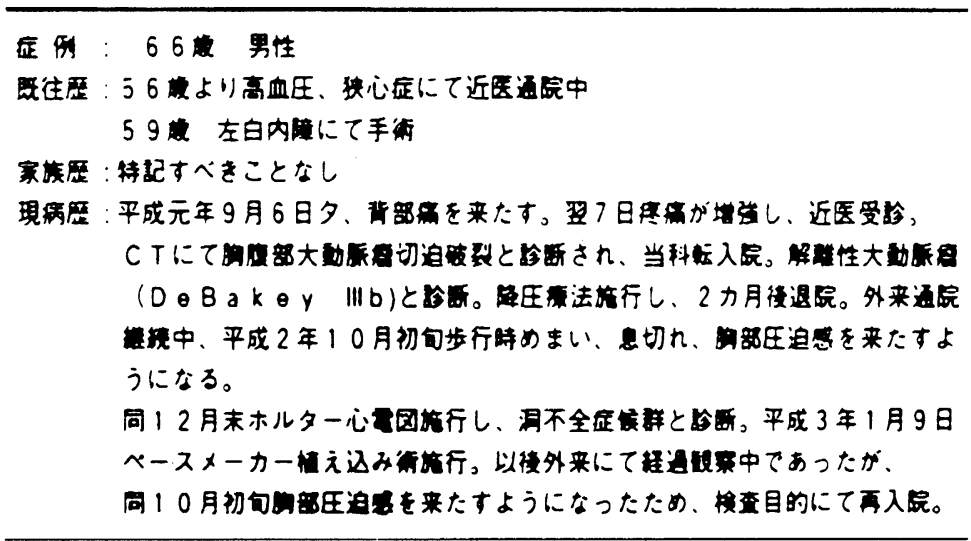




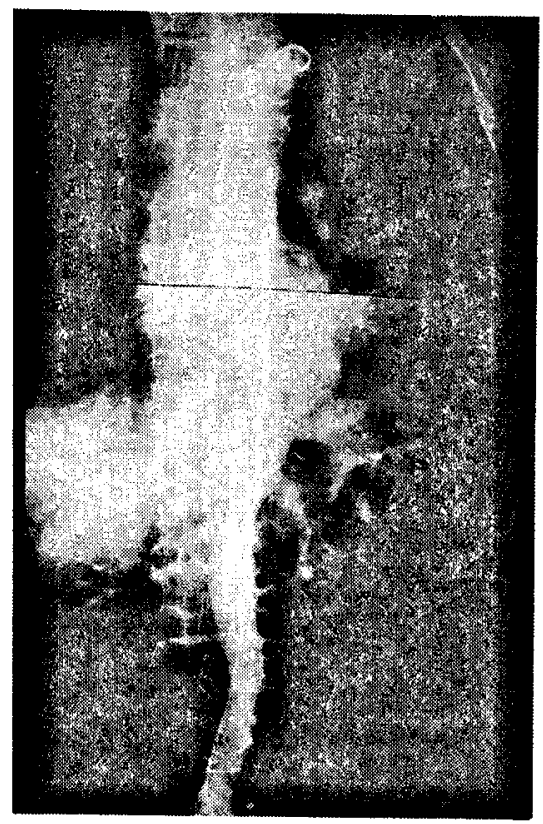

図 1 大功脈造影

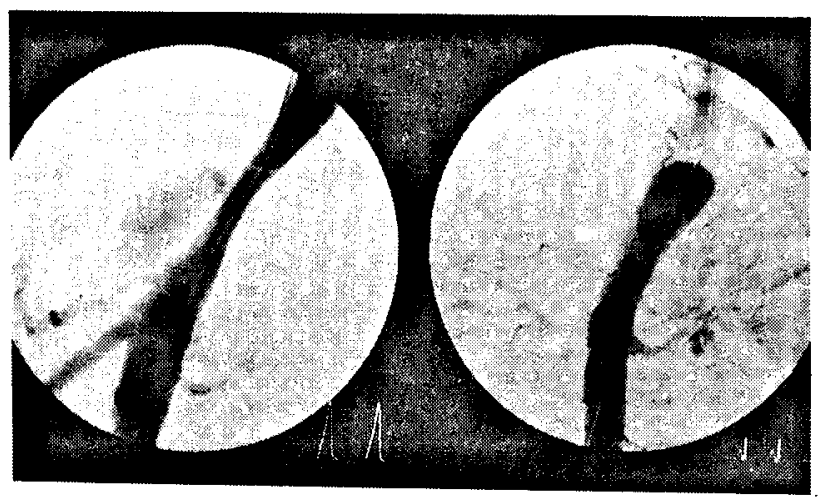

図 2 大動脈㾞

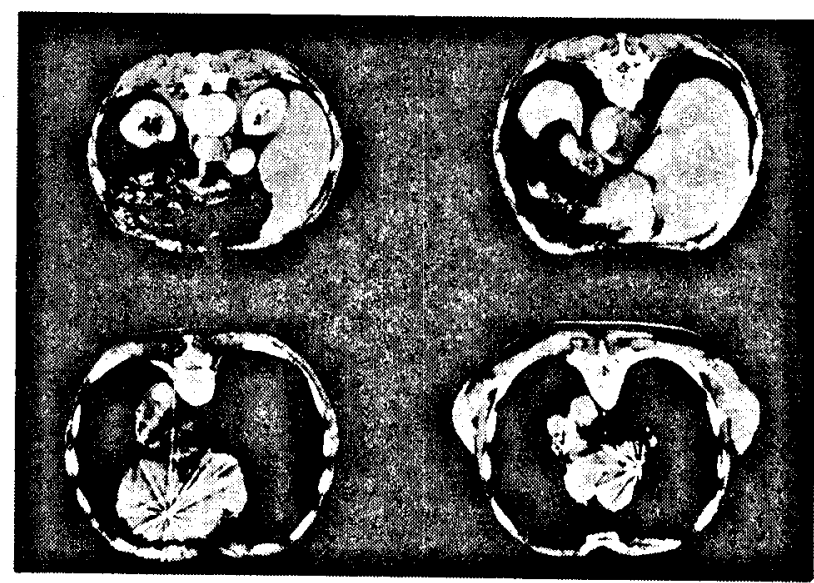

图 3 C T像

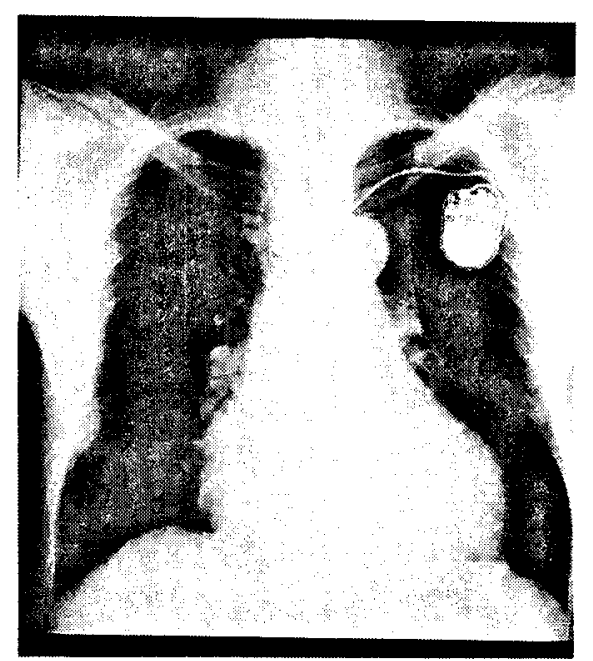

図 4 沟部単蚛
CapioxE，上行大動脈送血は，ボンプヘッドのみ $1 / 2$ inch とした $3 / 8$ inch チューブを使用し，大腿 動脈送血は， $3 / 8$ inch チューブ, 腹腔動脈送血は $1 / 4$ inch チューブを使用した（図5)。

術前へマトクリット値は42\%であった。充塓量

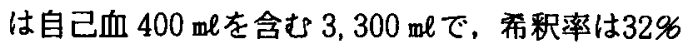
であった。

\section{IV. 手術および体外循環経過}

患者は右半側臥位とし，手術台の回転により仰 臥位および右側臥位をとれるようにした。まず仰

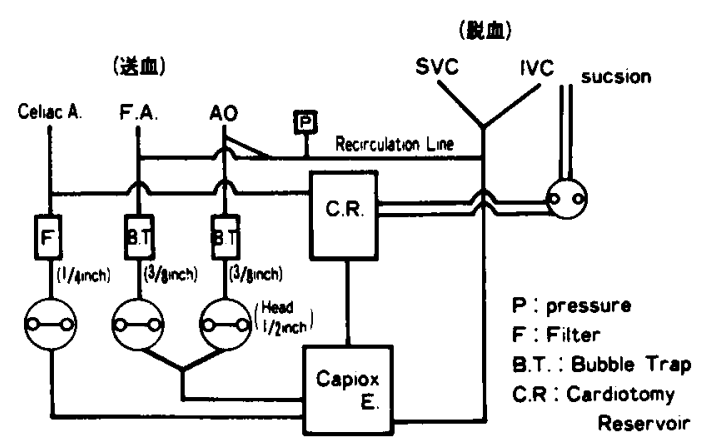

图 5 分醮体外语桭回路図 
臥位にて胸骨縃切開を加え，心膜切開した。次い で右側卧位とし, 左第 7 肋間開胸，下行大動脈を 露出した。左腎動脈, 上腸間膜動脈, 腹腔動脈を それぞれ剥離、テーピングしだ。ここで再び仰卧 位亡し, 上行大動脈汇送血管 $8 \mathrm{~mm}$,上・下大静脈 $9.10 \mathrm{~mm}$ 脱血管を挿入し体外循環を開始した。

上行大動脈を遮断し，灌流量 4,200 ml（index $\left.2.6 \ell / \mathrm{min} / \mathrm{m}^{2}\right)$ となったとてろで, Young-G I K 注入にて心停止を得, 右房を切開し中隔欠損をパ

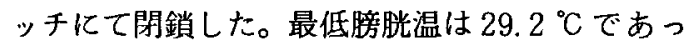
た。大動脈遮断を解除した後, 心拍再開は良好で 約30分後ウィニングを行い, 送血量が $1,000 \mathrm{m \ell} /$ min となったところで, 新たに左大腿動脈に B A R D22 Fr カニューラを挿入。復温後上行大動脈の 送血を中止し, 自己拍動を保ち, 大腿動脈送血を $2,000 \mathrm{~m} \ell / \mathrm{min}$ で開始し, 部分体外熖環とした。 ここで再び右半側卧位とし, 動脈溜の上下で下行 大動脈を遮断し，末梢側は腎動脈之上腸間膜動脈 の間で遮断した。次に腹胫動脈と上腸間膜動脈の 根部を鍔状にくりぬき, 腹腔動脈に, 住ベメディ カル製12Frカニューレを挿入し, 灌流量 $200 \mathrm{m \ell} /$ min で行った。大腿動脈からの送血量は 2,000〜 $3,000 \mathrm{~m} \ell / \mathrm{min}$, 下肢の平均灌流量压は $60 \mathrm{~mm} \mathrm{Hg}$ 以 上で経過した。上肢の圧は収縮期血圧で $100 \mathrm{~mm} \mathrm{Hg}$ 以上を保つようにした。

人工血管置換後, 腹腔動脈之上腸間膜動脈を再 建した。体外循環終了時最終希釈率は45\%, へマト クリット值は $23 \%$, 出血量は 815 , 尿量は $725 \mathrm{~m} \ell$, 追加輸液量は心筋保護液を含んで $3,650 \mathrm{~m} \ell$, 輸血 は2,000 mlであった。上行大動脈遮断時間は55分, 下行大動脈遮断時間は 3 時間 40 分, 総体外循環時 間は 5 時間40分であった（図6）。術後脊髄横断

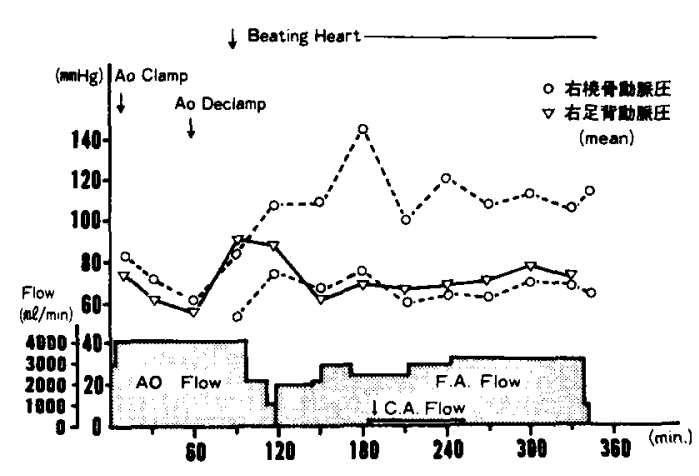

図 6 体外循環経過

症状を呈し，1か月後心囊ドレナージを必要とし たが全身状態は良好で現在りハビリテーション施 行中である。

\section{V. 考 察}

心疾患と大動脈瘤が合垪した場合の 1 期手術の 場合, 通常は心疾患手術を先行させ, 部分体外偱 環下または体外循環停止後に，大動脈瘤手術を行 う方法がとられている。今回の例でもA S D閉鎖 後に引き続き部分体外循環下に胸腹部大動脈瘤の 人工血管置換術を行った。また，今回の回路は， 送血に $1 / 2 ， 3 / 8 ， 1 / 4$ inchを使用し, 充堤量が

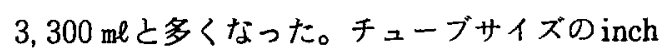
down等を行い, 充填量の節減が今後の課題であ る。

\section{考文 献}

1) 上山武史 : 分離体外循環と人工血管. 教育セミナ 一テキスト第 7 号，(39-48），日本体外循環技術 研究会, 東京, 1991. 